\title{
ARCHAEOLOGICALLY DOCUMENTED BUILDING MATERIALS AND TECHNIQUES USED FOR CIVIL AND RELIGIOUS MONUMENTS IN WALLACHIA, XVI - XVII CENTURIES
}

Dana Mihai

The analysis of building materials and techniques is important for at least two reasons. In the first place, any information of this kind contributes to a more precise dating of the different construction phases, when the other archaeological documents are uncertain. In the second place, the main purpose for the archaeological and architectural investigations is the obtaining of an as close as possible to reality picture. Thus, the information related to the presented topic help to the reconstitution of the monuments' initial architecture, an argument of uppermost importance to a historical restoration.

The subject regarding the building materials and techniques has been studied especially in the Architecture History treaties, by direct observations made by architects during restoration works. This subject was studied for the first time by Nicolae Ghika - Budești ${ }^{1}$, who observed the correlation between the existing building materials from an area and the builder's technical means.

Ghika-Budesti ${ }^{2}$, Grigore Ionescu ${ }^{3}$, Cristian Moisescu ${ }^{4}$ agreed on the building methods, of Byzantine origln, combined with the creativity and imagination of the local craftsmen.

Ghika-Budesti ${ }^{5}$ and Horia Teodoru ${ }^{6}$ mentioned the building technique of Byzantine origin, of the "wood pullers", widespread in the Romanian architecture?, this method being largely archeologically documented.

\section{Building materials}

The archaeological investigations have discovered, by their specific features, the building materials used by the medieval craftsmen. In the following pages we shall count the building materials used in the Wallachian medieval architecture, presenting also their chronological evolution.

\section{I.a. The bricks}

The main building material used in the XVI - XVII centuries was the brick, the only prefabricated element in the old Romanian architecture ${ }^{\theta}$. The bricks were made in the previous year to the yard opening, as the brick craftsmen needed to know the quantity to manufacture, as well as the requested formats and dimensions, according to the customer's order?.

\footnotetext{
'Ghika - Budeși, Evolution of architecture in Wallachia and Ottenia, 1927, p. 125.

${ }^{2}$ Ghika - Budeşti, History of architecture in Romania, 1931, p. 15.

${ }^{3}$ Ionescu, 1982, p. 93.

${ }^{4}$ Moisescu, 1985, p. 27.

${ }^{5}$ Ghika - Budeşti, 1927, p. 126 şi um.

${ }^{6}$ Teodoru, 1975, p. 621-624.

'Teodoru, 1975, loc. cit.

${ }^{8}$ Ghika - Budeşti, 1927, p.125, 1931; p. 15, 1933, p. 15, Ionescu, 1982, p. 90, Moisescu, p. 25 - 30.

9 Ibidem, p. 25.
} 
The architects Ghika-Budesti $^{10}$, Grigore Ionescu ${ }^{11}$, Cristian Moisescu ${ }^{12}$ ascertained the quality of the XVI century bricks, with polished surfaces and regular edges, superior to the quality of the bricks manufactured in the following century in what regards the surfaces and angles, but qualitatively inferior in what regards the burning technique ${ }^{13}$. This opinion was refuted by the direct observations made by archaeologists by researches on historical monuments.

The altering of the bricks' dimensions in the XVII century was due to the use of more complicated vaulting systems, corner trumpet and dome of pendentives ${ }^{14}$. From another point of view, the axchaeological researches nuanced the question's oata, being observed that a standard dimension had not been reached yet. Even though the bricks evaluated towards smaller lengths and widths, there are still numerous exceptions, thus being impossible the dating based only on the bricks dimensions. Nevertheless, most of the times the use of different formats allowed to determine different construction stages.

\section{Special bricks}

The exterital decoration of the churches and civil ouildings proved necessary the manufacturing of special shaped bricks. Thus, the cavette was used for the socles, the rectangular or tours shaped brick, disposed in serrated fashion was used for mantelpiece, while for the cornice the bricks were rectangular with apex.

Special bricks were discovered as result of the archaeological and architectural researches from the Târgoviste Royal Court, Cobia, Mihai Vodã, Steled, Strehaia Monasteries ${ }^{15}$, etc. (PI3/1-3)

As result of the archaeological researches from the monastic ensemble from Cobia, Dâmboviţa County, several types of bricks were discovered, provenient from the church socle or cornice, as well as in the steeple area, proving the bricks shapes diversification process, that had already evoluted towards the end of the XVI century ${ }^{16}$. (PI.1/3)

\section{I.b. The wood}

The wood represented a widespread material in the Wallachian architecture, used for scaffoldings, tie bars, wooden piles, "roofs"17.

\footnotetext{
${ }^{10}$ Ghika - Budeşti.

"Ionescu, 1982, p. 94.

12 Moisescu, 1985, p. 26.

${ }^{13}$ Ghika - Budeşti, 1933, p. 13.

14 Moisescu, 1985, p. 26. Brick sizes are $22 \times 12 \times 3.3 .5 \mathrm{~cm}$.

15 Puscasu, Dosar DMI, 8618, p. 16. Following the archaeological researches carried out at the monastic assembly from Strehaia, 7 brick types were discovered whose sizes and destination will be presented are as it follows: 1 . Bridk from the XVIth century used in the building of the outlining wall; church, rooms and bell tower with sizes of $25 \times 13 / 13.5 \times 4 \mathrm{~cm}$. (pl. IIl/1); 2. Brick from the XVIth century used in the building of the main building. $34 \times 17 \times 6 / 7 \mathrm{~cm} ; 3$. Brick worked in special shape used in the building of rounded girdles from the church, bell tower and royal house. $26 \times 13 \times 4 \mathrm{~cm} ; 4$. Brick worked in special shape used in the building of MULURILOR that outline the blind OCNIIE from the church, bell tower and royal house. $29 \times 9 / 10 \times 4 \mathrm{~cm}$ (PI. III/1); 5. Brick worked in special shape used in the building of the church, bell tower and royal house cornices. $26 \times 9 / 10 \times 4 \mathrm{~cm}$.; 6 . Brick from the inner pavement of the church. 30x8/9x3 cm.; 7. Brick of unknown provenience found inside the church (2 pieces). $20 \times 8 \times 3.5 \mathrm{~cm}$.

${ }_{16}$ Puşcaşu, dosar DMI, 6275. The archaeological researches were carried out in September 1970 (PI. I/3). The first brick type had undetermined length, width of $8.5 \mathrm{~cm}$ and thickness of $4.5 \mathrm{~cm}$. It has been enameled in green and yellow; 2 . Special type brick with one of the narrow sides rounded and enameled in greep. Length $=27 \mathrm{~cm}$, width $=9 \mathrm{~cm}$, thickness $=4 \mathrm{~cm}$. the rounded side is $3 \mathrm{~cm}$ long; 3 . Special type brick with concave profile. Length $=15 \mathrm{~cm}$, thickness $=4 \mathrm{~cm}$.; 4 . Common fragmented construction brick. Length unknown, width $=16 \mathrm{~cm}$, thickness $=5 \mathrm{~cm}$.; 5 . Special type brick with one of the narrow sides rounded with enameled edge. Length unknown, width $=14 \mathrm{~cm}$, length of the rounded part $=10 \mathrm{~cm}$.; 6 . Common construction brick. Length $=21 \mathrm{~cm}$, width $=12 \mathrm{~cm}$, thickness $=3.5 \mathrm{~cm}$.

${ }^{17}$ Grigore Ionescu (1982, p.45) has extensively described the use of wood in popular architecture, where it was used in the building of wooden churches "using 4 stripes beam" joined in "swalow tail" system.
} 
The beams' assembling technique using the "willow tail" system was also archaeologically documented at the wooden church from Vadu Sorești, Buzãu County ${ }^{18}$.

The wood was tied with wattle and clay mortar, as probably used also at the wooden church from Mãxineni, Brãila County ${ }^{19}$, and archaeologically documented reality.

\section{I.c. Stone}

A material used on a more restricted scale in the Wallachian architecture was the stone, due to the lack of extracting quarries. Nicolae Ghika-Budesti mentioned that in the XVIth century ${ }^{20}$, the stone lacked almost completely, being used only for the frames of doors and windows, being used on a larger scale during the Matei Basarab's time ${ }^{21}$.

Stone profiles discovered by Virgiliu Drăghiceanu ${ }^{22}$ at the royal house from Curtea de Arges were used afterwards by Pavel Chihaia as arguments for dating the house in the first quarter of the XVIth century ${ }^{23}$, together with the door framing being part of the same building stage. Subsequently the archaeological researches carried out have proven that the entire court has been rebuilt in the beginning of the XVIth century (PI. I/1).

The stone brought on the construction site in row state and chiselling and shaping processes followed. The stone processing was costly and difficult. During the processing one third was lost and the waste had to be removed from the site. The study of the stone facades for churches Dealu (1500) and Curtea de Arges (1517) has lead to the conclusion that the stone was processed on the construction site in order to check permanently the sizes of mounting grooves in the building brickwork ${ }^{24}$.

A compulsory rule for the quarry faced ashlar was its placing according to the natural strata position resulted from the sedimentation in the quarry, elementary rule that had to be known by every stone cutter 25 , otherwise according to Maurice Vieux's phrase, that one was guilty of "delictual cutting"26.

The sleeked stone was used on a large scale for pavements, stairs and cross basement, especially in the XVIth century ${ }^{27}$.

\section{I.d. Ceramics}

According to Nicolae Ghika-Budeşti's opinion, ceramics was used only during Matei Basarab's reign ${ }^{28}$, although its use has been documented afterwards from the XIIth century, at the church Arges $\mathrm{I}^{29}$, and then in the XIVth century, at the church of Cotmeana monastery, Tutana I and at the chapel of the old royal court from Târgovişte.

\footnotetext{
${ }^{11}$ Drâmbocianu, 1993, p. 487, fig. 13.

19 Candea, 1996.

${ }^{20}$ Ghika - Budeși, 1931, p. 16

${ }^{21}$ Ghika - Budesti, 1933, p. 14

2 Drăghiceanu, 1917 - 1924, p. 148

${ }^{2}$ Chihaia, 1974, p. $86-87$

${ }^{24}$ Moisescu, 1985, p. 27

25 Ibidem

26 Vieux, 1981, p. 164

${ }^{27}$ Moisescu, 1985, p. 27

${ }^{28}$ Ghika-Budest menntioned about the use of enameled bricks since Matei Basarab's time, starting with the construction of the church Stelea Veche from Targoviste, 1933 p. 14

${ }^{2}$ Constantinescu, 1984, p.141, fig. 68.
} 
The ceramics was used in the architectural decoration, as buttons, disks, plates of enamelled ceramics, as covering material of roof and gutter tile types ${ }^{30}$. (PI. I/2)

An unusual use of ceramics was documented at the church of monastery Tismana, Mehedinti district, where it served as material for horizontal waterproof insulation. Two rows of ceramic plates with glazed edges were discovered that prevented the rising of the high humidity from that zone ${ }^{31}$.

\section{I.e. Mortar}

The mortar of hydraulic cement with edded btoken brick was currently used in the époque as binding material. In order to obtain mortars with increased hydraulic properties, substances containing silica and alumina that reacted easily in combination with the chalk were added to the common mortar composition ${ }^{32}$.

For this purpose small fragments of brick were also used in the composition for the brickwork mortars in the inner and outer plasters ${ }^{33}$.

The literature ${ }^{34}$ stated that the mortar joints ${ }^{35}$ had the same thickness with the bricks, for economy and stability, because they insured a homogenous distribution of the supported weight.

Of another opinion was Grigore Ionescu ${ }^{36}$, who showed that mortar joints were mentioned narrow, between $1.5-2.5 \mathrm{~cm}$. This opinion was contradicted by the archaeological researches. Almost all mortar joints were $3.5-4 \mathrm{~cm}$ thick, filling out the horizontal and vertical ${ }^{37}$ gaps between the bricks.

In Wallachia, the joints had reached a thickness equal to the bricks' one in order to ensure the building stability, necessary in a seismic zone, but also for economy. The mortar was more easily prepared and therefore from the joint thickness resulted an economy of material.

The differences in composition between the foundation and elevation mortars in comparison with those used in the pavements were noticed archaeologically. Thus, if hard almost compact mortar mixed with pounded bricks was used for the foundation and elevation building, a sand-rich friable mortar was noticed in the pavements. The explanation consists in the provisions taken by the masons to ensure a good link between the foundation and elevation walls, while the easily degrading pavements had to be changed without to many problems ${ }^{38}$.

However, weak mortars used in foundations were also noticed. The friable mortar from the foundations was the cause leading to the demolition of the Runcu-Gradinari church ${ }^{39}$, Olt district. This type of mortar was noticed also at the church of Polovragi monastery ${ }^{40}$.

\footnotetext{
${ }^{30}$ The archaeological researches led to the discovery of enameled roofing tiles used to cover the royal church from Targoviste.

31 Moisescu, 1985, p. 28

3 The sand used for the lime mortar was quartzitic from which tha muddy impurities were washed away, with grain size of 4 mm. It has been noticed that the building-workers could establish the ratio between fine grained and coarse grained sands, in order to obtain a compact mass with as less holes as possible that were filled with binder.

33 Moisescu, 1985, p. 26

${ }^{34}$ Moisescu, 1985, p. 27

${ }^{35}$ Curinschi - Vorona, 1996, p. 237

${ }^{3}$ Ionescu, 1982, p. 92

${ }^{37}$ At the church of monastery Catalui, Calarasi district, $3.5-4 \mathrm{~cm}$ thick mortar joints were documented. Cantacuzino 8 Trohani 1981, p. 282. The joints are also met at Comana, Giurgiu district; Batrana, RMM, 1/1974, p. 21, Sf. Spiridon Vechi from Bucharest, Stefanescu, RMM, 1/2, 1993/1994, p. 97.

${ }^{3}$ At the churches from Tutana, Comana, Cotroceni a very strong mortar was used in the elevation.

${ }^{3}$ Constantinescu, 1959, p. 721

${ }^{4}$ I. Cantacuzino, 1994, p. 11
} 
Recent researches on the mortar samples taken from three distinct points in Târgovişte, the Pârcalab's House (1350), the Royal House from Mircea cel Battrân's reign, the walls of the royal court risen up during Petru Cercel's reign, have proven that the mortar used in the buildings of the XVIth century contained brick fragments of about $1 \mathrm{~cm}$ and had a lower porosity and higher quallty in respect with the other materials used. Thus the existence of an evalution of the building techniques during Petru Cercel's reign was highlighted also in what concerns the mortar composition ${ }^{41}$.

II. Aspects of the archaeological research contribution concerning the knowledge of materials and techniques used in the building of religious and civilian edifices

Archaeological investigations contributed also to the knowledge of the building materials and techniques of that time. We shall present further on parts of the data provided by the archaeological investigations concerning the constituent elements of an edifice.

In our classification we took into account two criteria:

1. Materials used

2. Building technique

\section{II.1. Foundations}

Building details concerning the foundations were observed during the archaeological investigations that partially or totally revealed them. As a general remark, one can notice the negligence in foundation outlining, leading to irregularity and thickness unevenness. The situation could be explained by the real outlining existing at elevation level. Differences between the foundation depth and thickness of wooden and wall churches. Thus, the depth of the wall churches foundations had to be $-1.10 \mathrm{~m}$ (frost depth), different from the wooden churches' one. These ones, having a much lighter superstructure had shallower foundations $(0.20-0.40 \mathrm{~m})$.

In some cases, due to the swampy ground, but also to the greater sizes of the churches which had to be sustained, unusual foundation depth existed. The foundation of the wooden church from Mãxineni, Brãila district (thickness $0.90-0.95 \mathrm{~m}$, depth $2.40 \mathrm{~m}$ ) is an exception explainable by the higher freatic watertable and a soil liable to flooding.

As a result of the same cause, the situation is repeated at the wall church Maxineni, Braila district, with very high foundation depth $(2.74 \mathrm{~m})^{42}$.

Very deep foundations have other reasons too. At the church Sf.Gheorghe Nou from Bucharest $^{43}$ they are found at $-3.14 \mathrm{~m}$, due partly to the three superposed monuments and to the greater sizes of the church build by Constantin Brâncoveanu.

\section{Foundation types}

In respect with the used materials four types or foundations were documented: boulders, boulders and bricks, stone, brick.

\footnotetext{
${ }^{41}$ Noica, "Romanian traditons in public building construction", 1997, p. $200-203$. An optimization of the grain size composition was noticed in Petru Cercel's time in respect with other periods, having as consequence the increase of apparent density and the reducing of mortar porosity.

Candea, 1996, p. 35

${ }^{4}$ Rosetti, Panait, 1962, p. 101
} 


\section{II.1.a. Foundations made up of boulders}

The high frequency of this type of foundation is explainable by the easiness to obtain a material that did not require processing and that implied, by its bulk, an economy of material.

Foundations made up of boulders binded with metar were widespread in the XIV-XVIth centuries $^{44}$, being more characteristic to the wooden churches rather to the wall ones.

Fourteen foundations were observed at the wooden churches from Maxineni" ${ }^{45}$, Braila district, Vadu Soreşti, Buzåu district ${ }^{46}$, Drujeşti 1 from Curtea de Arges ${ }^{47}$, as well as at Ursaţ, Gorj district ${ }^{48}$ and Valenii de Munte, all of them dated in the XVIIth century ${ }^{49}$, and also at the wall churches from the regions were the material was easy to obtain, such as curches 1 and 2 from Oraşul de Floci, Ialomiţa district ${ }^{50}$, as well as at the first church from Polovragi, Gorj district ${ }^{51}$.

\section{II.1.b. Foundations made up of boulders and brick fragments}

This type was noticed at monuments from the XVI-XVIIth centuries, where, useless brick fragments were thrown in the foundations together with boulders.

Such foundations were cbserved at the chapel from Domnestit ${ }^{52}$, Valea ${ }^{53}$, Vieros ${ }^{54}$, Tutana, from Arges district ${ }^{55}$, at the church no. $3^{56}$ from Oraşul de Floci, Ialomiţa district ${ }^{5}$ and RuncuGrădinari, Olt district ${ }^{58}$.

\section{II.1.C. Foundations made up of stone}

They were documanted in the XIVth century ${ }^{59}$, being lesser used. The church of Govora monastery, risen up by Constantin Brâncoveanu, had a foundation made up of broken stone and mortar 60 .

\section{II.1.d. Foundations made up of brick}

They were observed starting with the end of the XVth century, at the wooden churches from Râncarciov and Comana ${ }^{61}$, as well as at the wall churches from the second half of the XVIth century (at Cernica and Comana, where the foundations are made up of even size bricks binded together with

\footnotetext{
4 Rosett, Panait, 1962, p. 93

45 Cándea, 1996, p. 43

* Dråmbocianu, 1993, p. 469 - 478

${ }^{47}$ Cristocea, 1990 , p. 26

40 Radulescu, 1984, p. 181

- Bătâna, 1981, p. 234- 258

${ }^{50}$ Chitgescu and co-workers., 1981, p. 120

51 I. Cantacuzino, p. 11

5 Cristocea and co-workers., 1987, p. 35

${ }^{53}$ Márzu, 1978, p. 635

54 Cristocea and co-workers., 1996, p. $20-21$

${ }^{55}$ Cristocea, Oprescu, 1988, p. 49

56 Chitescu and co-workers, C.A., VI, 1983, p. 75. At the church no. 3 from Orasul de Foci, Ialomita district an interesting system was noticed in the base of foundation trenches was placed a layer of large boulders binded together with lime mortar, over which the foundation proper was constructed.

${ }^{57}$ Chitescu and co-workers, 1986, p. 75

T Constantinescu, 1959, p. 721

9 In the XIVth century, foundations of stone plates are described at the church of monastery Cozia (Constantinescu, M.0./1965, p. 591). At the first church from Snagov, Ilfov district, bulld up of stone fragments and mortar; (I. Cantacuzino, Cronica, 1997, p. 57); in the XVth century, at the church of monastery Tanganu, Ilfov district (Panait, 1962, p. 93).

60 I. Cantacuzino, 1992, p. 32

${ }^{61}$ Cristocea and co-workers, 1993/1994, p. 25-32; Bătråna, 1974, p. 21.
} 
chalk, sand and gravel mortar ${ }^{62}$ ). They became preponderant in the XVIIth century in the zones where the stone lacked or was difficult to get.

Thus, at the churches Râncăciov, Arges district and Strehaia, Mehedinţi district, risen up during Matei Basarab's reign ${ }^{63}$, at the church from Turnu monastery, Târgşor, risen up by king Antonie in $1670^{64}$, as well as in the cantacuzine époque, at Cotroceni (1679) and Sf. Spiridon Vechi (1680) churches from Bucharest ${ }^{65}$, were discovered brick foundations have thickness of $0.80-1.20 \mathrm{~m}$, generally binded together with hard mortar, placed at almost constant depth of $-0.90--1.10 \mathrm{~m}$.

\section{II.2. Socles}

The socles of the churches had the role to dimish the thickness from the foundation to the elevation. In the XIV-XVIth centuries, a few monuments had socles. They appeared only in the XVIth century and were made up of gradually retreating simple bricks, and then of special brick and sleeked stone too.

II.2.a. Socles made up of sleeked stone were generally used at the monuments built up of the same material such as the churches of monasteries Dealu and Curtee de Arges ${ }^{66}$. (see PI. IV/1)

II.2.b. Socles made up of brick were made in the beginning by the successive retreat of three or more brick rows and were described following the archaeological researches carried out at the churches Cernica ${ }^{67}$, Cătălui, Călăraşi district ${ }^{68}$, Tutana, Arges district ${ }^{69}$, Comana, Giurgiu district ${ }^{70}$, Runcu-Grādinari, Olt district ${ }^{71}$ and Stelea Veche from Târgovişte ${ }^{72}$, all of them founded in the XVIth century.

Towards the mid-XVIth century, were used socles made up of special shape bricks, with one of the narrow edges sharpened. The profile was obtained combining all types of shaped bricks in cavetto (semicircle with the carved part outwards).

Ghika-Budesti ${ }^{73}$ considered the socle of the Bucharest royal church, founded by Mircea Ciobanul in $1559^{74}$, as the first socle profiled from special quartercircle bricks. Subsequent researches have proven that this one appears actually at the church of Cosuştea monastery, Mehedinţi district (1475) studied by Alexandru Bărcăcilă ${ }^{75}$. (PI. IV/2)

An interesting socle from the building point of view was discovered during the face of wall study of the royal church from Târgovişte. It consists of a brick work of badly carved and jointed plates, plastered afterwards, ending in the upper part with a row of special shaped bricks ${ }^{76}$. (PI. IV/3)

\footnotetext{
2 Cantacuzino, Trohani, 1981, p. 200-235\$̣ Bătrâna, 1974, p. 17.

${ }^{6]}$ Cristocea and co-workers, 1993/1994, p. 25ş Cándea, 1996, p. 43.

${ }^{4}$ Constantinescu, 1969, p. 83-90.

${ }^{65}$ Ştefônescu, 1993/1994, p. 89-93ş Panait, 1990, p. 13-26.

66 Ghika-Budeşti, 1931, p. 143.

${ }^{67}$ Cantacuzino, Trohani, 1981, p. 202.

6 Cantacuzino, Trohani, 1979, p. 282

${ }^{69}$ Cristocea, Oprescu, 1988, p. 19.

"Bătrána, 1974, p. 21.

${ }^{11}$ Constantinescu, 1959, p. 72.

7 l. Cantacuzino, 1974, p. 40.

7 Ghika-Budesti, 1927, p. 127.

${ }^{74}$ Ghika-Budesti, 1931, p. 26-27.

75 Barescila, 1935, p. 165-184.

' Mănciulescu, 1963, p. 34-37.
} 
The socles made up of bricks were often covered in plaster and painted, such as the documented ones from Sf. Gheorghe Nou ${ }^{77}$, Govora ${ }^{78}$, Râmnicu-Sărat ${ }^{79}$, Stelea Veche of Târgovişte ${ }^{80}$.

\section{II.3. Types of elevations}

In the Wallachian architecture four types of elevations are known: boulder, stone, stone and bricks, bricks.

\section{II.3.a. Elevation made up of boulders}

It was documented in the case of the chapels from Domnesti $i^{81}$ and Suslanesti ${ }^{82}$, Arges district, modest buildings, risen up with handy materials and walls worked in a careless enough manner.

\section{II.3.b. Elevations made up of stone}

Due to the high price of stone processing, yielding and evacuation off the building site, this material was lesser used in the Wallachian architecture, being met at the churches of monasteries Câmpulung and Curtea de Arges, as well as Dealu from Tárgovişte.

At Câmpulung, the face of the wall was formed of paralelipipedic blocks of sleeked stone, high of $0.30 \mathrm{~m}$. The blocks of the lower seating have smaller sizes and the joints are a little bit smaller. In places, between the blocks of the first seating and the the superposed ones, equalising bricks were interlayer ${ }^{\mathrm{B}}$.

\section{II.3.c. Elevation made up of stone and bricks}

Of Byzantine tradition, characteristic to the XIV-XVI centuries, it has been seldom used in the XVIIth century. It has been documented in the beginning of the XVIth century at the churches $2^{84}$ and 3 from Oraşul de Floci, Ialomiţa district, where the walls have been worked out of bricks and stone fragments ${ }^{85}$, as well as at the church of monastery Catalui, Calaraşi district, risen up in the midXVIth century where the same type of bricklaying was used, worked in emplecton ${ }^{86}$.

\section{II.3.d. Elevation made up of bricks}

It has been used since the XIVth century at the church Cotmeana and at the chapel from Târgovişte.

\footnotetext{
$\pi$ Panait, 1990, p. 104.

刃o I. Cantacuzino, 1994, p. 32.

${ }^{79}$ Lupu, 1994, p. 275.

00 1. Cantacuzino, 1974, p. 40.

${ }^{61}$ Cristocea and co-workers, 1987, p. 20. In the western wall of the pronaos from the church of Domnesti, Roman bricks were also used.

Rosetti, 1972, p. 27.

${ }^{\text {es }}$ I. Cantacuzino, 1980 , p. 134.

on Chitescu and co-workers, 1981, p. 139.

${ }^{05}$ Idem, 1985, p. 75.

* Cantacuzino, Trohani, 1981, p. 282.
} 
In the mid-XVIth century, brickwalls have been documented at the curches Sf. Francisc ${ }^{87}$ and Stelea Veche from Târgovişte ${ }^{88}$.

Starting with the second half of the century the examples multiplicate, brick elevations being described at the church Runcu-Grãdinari, Olt district ${ }^{99}$, at the church of monastery Vieros, Arges district $^{90}$, at Comana, Giurgiu district ${ }^{91}$, in the second phase of church 1 , and at churches $2^{92}$ and $3^{93}$ from Oraşul de Floci ${ }^{94}$, Ialomiţa district.

The brickworks of the XVIIth century are built still in rows of river boulders alternating with rows of bricks, or only in rows of bricks which are plastered and painted in red. As early as Matei Basarab's reign the system of brick elevations starting even from the foundations ${ }^{95}$ is met. Thus, this aspect was described at the churches of the monasteries founded during Matei Basarab's reign at Strehaia, Mehedinţi district ${ }^{96}$, Râncăciov, Arges district ${ }^{97}$, Maxineni, Braila district as well as the cantacuzian monuments, at the churches of monasteries Turnu from Târgșor ${ }^{99}$, Sf. Spiridon Vechi ${ }^{99}$, Cotroceni from Bucharest ${ }^{100}$, and of course also at the monaments from the brancovinian époque, such as the hermitage Sf. Ioan from Hurezi, Vâicea district ${ }^{101}$.

At the church of Maxineni ${ }^{102}$ monastery a very thick brick was used $(28 \times 16 \times 5 \mathrm{~cm})$, due probably to the inappropriate ground conditions. Almost the same type of brick was used at Râncăciov ${ }^{103}(27 \times 13.5 \times 4.5 \mathrm{~cm})$, at Strehaia ${ }^{104}(26 \times 13 \times 4 \mathrm{~cm})$, (see PI.III/1,3) and Vireos ${ }^{105}(29 \times 15 \times 4.5$ $\mathrm{cm}$ ). For the monuments of the cantacuzian époque almost a standardised ${ }^{106}$ brick format was reached, phenothenon continued also in the brancovinian époque.

\section{II.4. Inner and outer decoration}

The archaeological investigations have offered rich information on the inner and outer decoration of the monuments, important to follow the evolution of the facade adornment of religious buildings in the Wallachian architecture.

\footnotetext{
${ }^{87}$ Moisescu, 1979, p. 90.

1. Cantacuzino, 1974, p. 41.

Constantinescu, 1959, p. 719.

${ }^{90}$ Cristocea and co-workers, 1996, p. 27.

${ }^{91}$ Bătrâna, 1974, p. 20.

${ }^{2}$ Chitgescu and co-workers, 1979, p. 224.

${ }^{93}$ Chitescu and co-workers, 1985, p. 75.

Chitgescu and co-workers, 1979, p. 199.

${ }^{95}$ Curinschi-Vorona, 1982, p. 233.

* Puşcaşu, 1970, p. 41.

${ }^{97}$ Chiţescu and co-workers, 1996, p. 23.

Constantinescu, 1969, p. 91.

99 Ştefănescu, 1993/1994, p. 97.

100 Panait, 1990, p. 20.

${ }^{101}$ Rosetti, 1962 , p. 104.

100 Candea, 1996, p. 43.

${ }^{103}$ Cristocea, 1993/1994, p. 178.

104 Puşcaşu, 1970, p. 28.

${ }_{105}$ Chitescu and co-workers, 1996, p. 21.

106 At the church of monastery Turnu from Targsor was used a brick of $26.5 \times 13 \times 3.5 \mathrm{~cm}$. Ten years after at the church $5 f$. Spiridon from Bucharest was used a brick of $27 \times 14.5 \times 3.6 \mathrm{~cm}$ and in the beginning of the following century at Sf. Ioan from Hurezi, Valcea district, was documented a brick of $27 \times 12 \times 3.5 \mathrm{~cm}$.
} 


\section{II.4.a. Outer decoration}

The architectural investigations started at the church of monastery Gorgota, Dâmbovița district, have lead to the discovery of the median girdle formed by two rows of toothed placed bricks. This decoration appeared for the first time at the foundation of Radu cel Mare from Dealu ${ }^{107}$.

At the church of Runcu-Grãdinari, Olt district ${ }^{100}$, the archaeological researches have evidenced the existence of a two-layered brick tooth-shaped median girdle as well. This type of girdle can be observed also at the church of monastery Mihai Voda, Bucharest ${ }^{109}$.

At the church of monastery Catălui, Calaraşi district, were discovered bricks belonging to the external facades decoration, with concave or triangular ends and which were part of a girdle ${ }^{110}$ made up of rounded bricks, bordered by straps of tooth-like placed bricks ${ }^{111}$, met in that time also at Târgşor, Bucovaț ${ }^{112}$, Tutana ${ }^{113}$. At the monastery Sf. Troiţă, the outer decoration is made up of face bricks, as well as at the church Mihai Vodã, both of them from Bucharest ${ }^{114}$. (PI.III/2)

At the royal church and house from Târgovişte, built by Petru Cercel, was used a decoration system made up of a red painted plaster imitating a brick pattern around plasture panels ${ }^{115}$.

Following wall probing of the church of former monastery Maxineni, Braila district ${ }^{16}$, parts of the plasture layer imitating bricks were discovered as well as fragments of the outer decoration painted with insets.

At the church of monastery Turnu from Târgşor, the decorating system of the facades was represented by cornice panels, separated by a median girdle of tooth-placed bricks ${ }^{117}$.

In the XVI-XVIIth centuries, the churches were decorated with external fresco, as is evidensed by the painting fragments discovered near the disappeared churches of Domnesti ${ }^{118}$, Suslăneștiti" ${ }^{119}$ Cataluii ${ }^{120}$, Cernica ${ }^{121}$.

\section{II.4.b. Inner decoration}

During the digging, architectural fragments belonging to old buildings were discovered many times. They help to reconstruct the original architecture of the monument. Thus, at Râncarciov, Arges district was discovered a window fragment belonging to the second church ${ }^{122}$, and at Maxineni, Braila district part of the stone portal situated between the church porch and the pronaos ${ }^{123}$.

\footnotetext{
${ }^{107}$ Moisescu, 1979, p. 141

${ }^{100}$ Constantinescu, 1959, p. 720.

${ }^{109}$ Cantea (Cantacuzino), 1959, p. 99.

111 Theodorescu, 1968, p. 219.

${ }^{12}$ Ghika-Budesti, 1931, p. 15. initiated by this monument.

${ }^{114}$ Ionaşcu, Zirra, 1959, p. 63.

115 Constantinescu, Moisescu, 1969, p. 32.

116 Nicolae, 1982, p. 150.

${ }^{117}$ Constantinescu, 1969, p. 90.

${ }_{118}$ Cristocea and co-workers, 1987, p. 23, fig. 11.

119 Rosetti, 1972, p. 31.

${ }^{120}$ Cantacuzino, Trohani, 1979, p. 283.

121 Cantacuzino, Trohani, 1981, p. 218, fig. 9.

122 Cristocea and co-workers, 1993/1994, p. 178.

wa cándea, 1996, p. 87.
}

${ }^{110}$ Dragut, Encyelopedic dictionary of Romanian middle-age art, 1976, p. 69. The girdle had known many versions: 1. Stone twisted rope, at the church of monastery Curtea de Arges; 2. Ring betweten cavettes, at the churches of monasteries Tutana and Marcuta; 3. A ring between two rows of dentated bricks, at the church Bucovat, Dolj district.

${ }^{113}$ Cristocea and Oprescu, 1988, p. 46. The facades are divided into two registers of arched niches, with the back underlined by widths of bricks and the arches are supported by small columns built up of special bricks with a rounded side. The model was 
The widest met pavements in the religious architecture are made up of rectangular bricks as discovered at Domnesti ${ }^{124}$, Suslăneşti125, Cătălui ${ }^{126}$, Cernica ${ }^{127}$, Vieros ${ }^{129}$, the second pavement from Runcu-Grãdinari ${ }^{129}$, the royal church from Targovişte ${ }^{130}$, at Comana ${ }^{131}$, Maxineni ${ }^{132}$, Ursaţi ${ }^{133}$.

At Bucovăţ and Comana large format pavement bricks were used, with length of $50 \mathrm{~cm}$.

Another brick format was met at Vieros $(30 \times 16 \times 5 \mathrm{~cm})$. All other bricks have almost the same size, $28-30 \times 12-14.5 \times 3-4.5 \mathrm{~cm}$.

Pavements with hexagonal bricks are lesser met. They appeared in the XVIth century at the curches of the monasteries Comana, Valea, Tutana ${ }^{134}$. Square brick pavements are met at the churches Radu Vodă and Sf. Gheorghe Nou from Bucharest ${ }^{135}$.

Stone pavements were lesser used and were met at the churches Sf. Vineri and at the royal church from Târgovişte, in Brâncoveanu stage (stone slabs) ${ }^{136}$, at the church Bradu, Buzãu district ${ }^{137}$.

\section{II.5. Roofs}

In respect of the rnaterials used, four types of roofs are met: with gutter tiles, with roofing tiles, with wooden shingles and with metal sheets.

In this field also one can notice the dependence of the materials which existed in the neighbouring region. Thus, in the plains gutter tile roofing were preferred, of old byzantinian tradition and suitable for low-angle slopes ${ }^{138}$. In the mountains wooden shingles were preferred.

II.V.a. Roofs made up of roofing and gutter tiles have been documented at the churches of monasteries Bucovăt, Dolj district ${ }^{139}$, Stănești ${ }^{140}$, Comana, Giurgiu district (enamelled green and yellow gutter tiles) $)^{141}$ and Cătălui, Călăraşi district ${ }^{142}$.

At the royal ohurch from Târgovişte fragments of roofing tiles placed on an wooden framework $^{143}$. (PI. I/2)

II.V.b. Roors made up of wooden shingles existed more in mountain regions, where wood was to be found, at Brădet, Căluiu, infirmary of the monastery Cozia ${ }^{144}$. According to historical

\footnotetext{
124 Cristocea and co-workers, 1987, p. 23.

${ }^{125}$ Rosetti, 1972, p. 27.

126 Cantacuzino, Trohani, 1979, p. 202.

${ }^{127}$ Cantacuzino, Trohani, 1981, p. 282.

12 Cristocea and co-workers, 1996, p. 21.

12 Constantinescu, 1959, p. 721.

130 Moisescu, 1979, p. 194.

131 Batrana, 1974, p. 22. It was used a large brick pavement, $50 \times 25 \times 9 \mathrm{~cm}$.

18 Cândea, 1996, p. 40.

${ }^{133}$ Radulescu, 1984, p. 181.

${ }^{144}$ Bătråna, 1974, p. 22, Mårţu, 1978, p. 631.

13s Ionaşcu, Zirra, 1959, p. 73; Rosetti, 1972, p. 28, Rosetti, Panait, 1962, p. 17.

${ }^{136}$ Moisescu, 1979, p. 194.

${ }^{137}$ Chicideanu, Modoran, 1983, p. 197.

10 Ghika-Budesti, 1931, p. 18.

${ }^{179}$ Ghika-Budesti, 1931, loc.cit.

140 Popescu-Cilieni, 1945 , p. 19.

141 Bătrána, 1974, p. 21.

10 Cantacuzino, Trohani, 1981, p. 283.

${ }^{143}$ Curinschi-Vorona, 1996, p. 269.

${ }^{14}$ Ghika-Budeşti, 1931, p. 18.
} 
sources, the church from Mamul and the royal church from Târgovişte were covered with wooden shingles ${ }^{145}$.

At the wooden church from Ursaţi, a shingled roof was supposed, supposition supported by the great number of thin nails discovered ${ }^{146}$.

The archaeological researches to not offec to many data in this respect because of wood perishables, but this type of roof was characteristic for the mountain regions. In the old catalogue of Arges district from 1817, the oak-wood shingle roof of the church Râncăciov, Arges district ${ }^{147}$, is mentioned.

II.V.C Roofs made up of tin sheets are documented at Cotmeana, Cozia, Dealu, the metropolitan seat of Târgovişte, Tismana, and for the XVIIth century. Others were covered with lead sheets, such as churches form Plumbuita, Gura Motrului and the patriarchal church from Bucharest ${ }^{140}$.

\section{Building techniques}

We shall present hereafter the building techniques signaled by the archaeological investigations, on main elements of a building.

\section{III.1. Techniques of foundation construction}

\section{III.1.a. Foundations on wooden poles}

The 'unsuitable ground (sloped or swampy terrain) for building has determined the placement of several wooden poles under the foundation in order to strengthen the underground.

At the church of monastery Curtea de Arges two rows of oak-wood poles were placed under the foundation ${ }^{149}$. Oak-wood poles were placed under the northern base of the altar abyss and under the pronaos western wall from Tutana. They were covered with layer of bricks and one of mortar ${ }^{150}$. A wooden pole was discovered under the foundation of the church vieros $\mathrm{I}^{151}$. The same technique was used at the church of monastery Cozia ${ }^{152}$, at Sf. Spiridon Vechi from Bucharest ${ }^{153}$ and at the Brâncoveanu hall of monastery Hurezi and at the curtain from Brâncoveni ${ }^{154}$. (PI. V/2,4)

\section{III.1.b. Terraced foundations}

The purpose of terraced foundations was to create in places a horizontal base on a sloped terrain. This technical solution was used since the XIVth century ${ }^{\mathbf{1 5 5}}$, and later on, during the XVI-

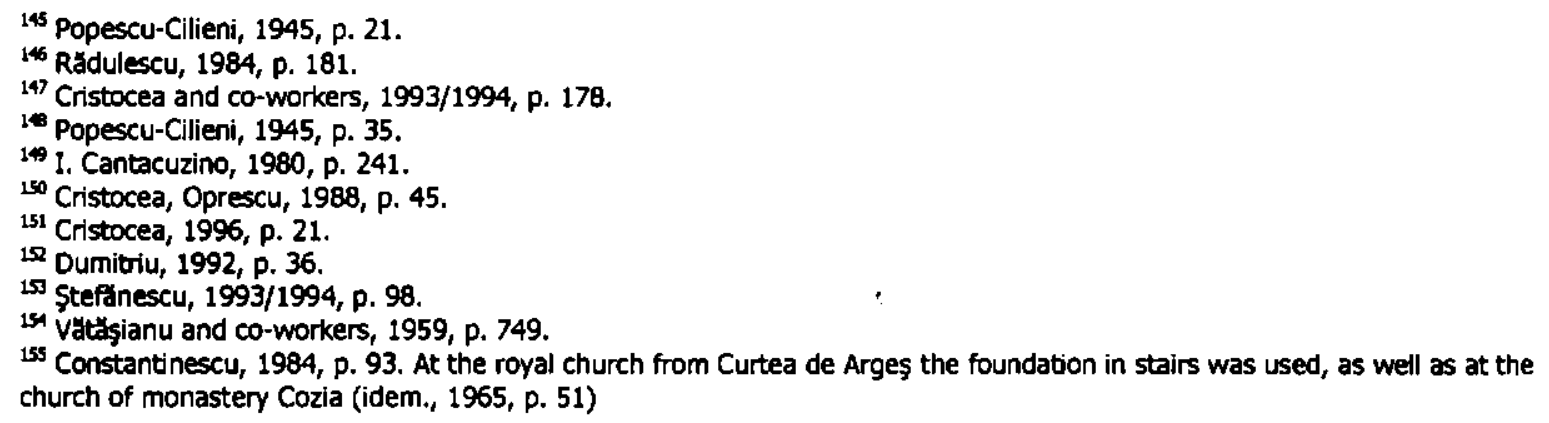


XVIIth centuries, at the chapel Suslănesti, Arges district ${ }^{156}$, Strehaia, Mehedinţi district ${ }^{15}$, at the foundation of the northern outlining wall from Brâncoveni ${ }^{158}$. (PI. V/4)

\section{III.1.c. Plated foundations}

The ingenious method of plated foundations was used since the XIV-XVIth centuries at the royal churches from Câmpulung ${ }^{159}$, Curtea de Arges ${ }^{160}$ and Târgovişte ${ }^{161}$, in short to every monuments with isolated points of support, where stresses had to be transmitted to the neighbouring perimeter walls by uniform overtaking, in order not to inflict disequilibria the constructive system.

\section{III.2. Masonry techniques}

\section{III.2.a. emplecton}

The masonry technique of the emplecton, known also as the method bottoming 162 "rottame di petre" was documented in the Wallachian architecture. The technique, with Roman origins, was taken over by byzantinians and applied on a large scale in the Wallachian architecture.

This method was characteristic to all types of elevations ${ }^{163}$. By using it, a great wall thickness was created. The external walls had the role of casing, the interior being filled up with boulders and stone fragments binded together with mortar.

The method offered a remarkable strength after mortar hardening, having the advantage of using low cost and easy-to-get materials. The technique was used since the XIVth century for the construction of the first royal houses in Târgovişte, Stelea Veche and Sf. Francisc from Târgovişte ${ }^{164}$, the church no. 1 from Oraşul de Floci, Ialomitga ${ }^{165}$ district as well as at the church of monastery Catalui, Calarasi ${ }^{166}$.

\section{III.2.b. Wooden girdles}

Wall stabilisation during the whole building time span was solved by overseeing the supporting walls on one hand, and by introducing in the bulk of the brickwork of wooden girdles placed in pairs from foundations to the cornice, at average distances of 2-2.5 m, on the other hand.

The technique is langely documented form archaeological point of view bath in the civilian and religious architecture starting with the XIVth century ${ }^{167}$. (PI. V/1,3)

A row of horizontal wooden beams were found at the church of monastery Vieros, dating from the XVIth century. They were placed at $30 \mathrm{~cm}$ from the joining between the foundation and the

\footnotetext{
156 Rosetti, 1972, p. 27.

15 Puscasu, 1970, pp. 28-36. In the church was brought leveling material (earth) in order to ensure a plane as near to the horizontal as possible due to the sloped terrain.

190 Vătăsianu and co-workers, 1959, p. 749.

${ }^{199}$ Draghiceanu, B.O.R, 3/1964, p. 316. The radier foundations were used at the monuments in greek cross plan. They were constructed with river boulders connecting the church columns.

${ }^{160}$ Constantinescu, 1984, p. 40.

${ }^{161}$ Information arh. Cristian Moisescu.

10 Drăguț, 1976, p. 59.

${ }^{163}$ Moisescu, 1985, p. 28.

${ }^{164}$ Moisescu, 1979, p. 90.

165 Chitescu and co-workers, 1969, p. 200. It was noticed that the masonry was worked in the interior using emplecton technique, and the wall had an impressive thickness of $1.5-2 \mathrm{~m}$.

166 Cantacuzino, Trohani, 1979, p. 282.

${ }^{167}$ Cristocea and co-workers, 1996, p. 21; Cantacuzino, Trohani, 1979, p. 276-304.
} 
elevation and were intercepted at the naos and altar abysses, where the beams were shorter so that their joining could follow the semicircular outline of the $a l t a r^{169}$.

\section{III.2.c. Settling joint}

The technique of the settling joint was applicable between two structures, with different volumes and weight. It was documented at the church Sf. Vineri from Târgovişte, where it was noticed the fact that the church porch has indepentend foundations of the main building. The same base internal level has determined their dating in the same stage of construction ${ }^{169}$.

The construction of the porch and the church in the same stage or in close stages was hypothetically admitted also in the case of the church Tutana I. The technical sense of the constructors as well as conditions of the fioundation ground have determined the Romanian master masons to design this joint between two structures that had to work independently of eachother, the porch and the remaining part of the church ${ }^{170}$.

\section{Technical solutions and construction errors}

\section{IV.1. New technical solutions}

Ofteh dealing with grounds not suitable for rising up a boilding, master masons have frequently used new solutions in order to remediate the possible difficulties.

The wet ground from Maxineni, Braila district, determined the master masons to burn the place, realising in this manner a protective stratum against the dampness ${ }^{171}$.

At the church Sf. Splridon Vechi from Bucharest, it was noticed the ingeniousness of the constructors who adapted to an unusual situation. Due to the high humidity of the ground the pavement of the church was designed with $20 \mathrm{~cm}$ over the base level, therefore the operating base level of the church was higher than the construction one ${ }^{172}$.

Church repairing where observed through archaeological researches, proving sense of sparseness and inventivity.

At the church of monastery Cernica I, Ilfov district, changes were designed leading to modifications of the church in the nave plan, with abysses deepened in the walls in a trefoiled plan (the so-called mixed type).

Following these changes, the churches becomes trefoiled by demolition of the naos lateral walls and the addition of two lateral absyses ${ }^{173}$.

The almost complete reuse of building materials was documented in the case of the church no. 1 from Oraşul de Floci, Ialomita district, where in the second stage of construction the stone foundation was strengthened, and the altar wall was placated with a row of bricks placed along its

\footnotetext{
${ }^{160}$ Cristocea and co-workers, 1996, p. 21.

169 Moisescu, 1979, p. 127.

${ }^{100}$ Cristocea, Oprescu, 1988, p. 57.

in Cándea, 1996, p. 37.

17 Ştefănescu, 1993/1994, p. 98.

17 Cantacuzino, Trohani, 1981, p. 208-209.
} 
width. Vertical bricks were interlayer between the recovered stone blocks on the southern side of the pronaos ${ }^{174}$.

Re-use of the older foundations was documented, by overlapping the foundations of two or three buildings maintaining the communion table position.

The superposition of churches could be explained by mental reasons, the church site being considered sacred, but also by economical reasons, through material reuse. Partial or total superposition of foundations were noticed in 18 cases from the XVI-XVIIth centuries. (PI. VI/1)

Church superposition were archaeologically documented in Prahova district, at vălenii de Munte $^{175}$, in Buzãu district at Bradu ${ }^{176}$, Maxineni ${ }^{177}$, Adormirea Maicii Domnului from Râmnicu Sărat ${ }^{179}$, in Ilfov district, at Snagov ${ }^{179}$, Cernica ${ }^{180}$, in Dâmboviţa district at Stelea Veche ${ }^{181}$, at church Targului ${ }^{182}$, in Arges district at Beştelei from Pitesti ${ }^{183}$, Tutana ${ }^{184}$, Valea ${ }^{185}$, Drujesti ${ }^{186}$,Vieros $I^{187}$, Rancaciov ${ }^{189}$, Campulung ${ }^{189}$, in Bucharest (PI.VI/2) at Sf. Apostoli ${ }^{190}$, Radu Voda ${ }^{191}$, Sf. Gheorghe Nou ${ }^{192}$.

At Biserica Alba from Bucharest, parts of the first church elevation were used in the construction of the second church, including the foundations ${ }^{193}$. The same situation is noticed at the church Sf. Apostoli from Bucharest ${ }^{194}$.

\section{IV.2. Construction errors}

Due to the undersizing of the foundation thickness and to its inadequate depth, some monuments have suffered important modifications, leading sometimes to monument fall down.

At the church Gherghitgi, the dome collapse was due its support using 4 arches positioned in console too much outwards in respect with the supporting walls ${ }^{195}$.

Because of the weakened founding ground following previous burials and the existence of neighbouring wholes, the walls of the church Runcu-Grãdinari, Olt district, have cracked ${ }^{196}$.

A certain awkwardness was noticed in the construction at the church Suslannesti, where the walls do not have even thickness ${ }^{197}$.

\footnotetext{
${ }^{174}$ Chitgescu and co-workers, 1979, p. 202.

1 B̧ Batuâna, 1981, p. 172.

$1 \%$ Chicideanu, Modoran, 1983, p. 191.

in Candea, 1996, p. 42.

178 Lupu, 1994, p. 273.

${ }^{17}$ I. Cantacuzino, 1997, p. 52.

im Cantacuzino, Trohanl, 1981, p. 200-240.

101 I. Cantacuzino, 1974, p. 41.

1.0 Chicideanu, 1973 , p. 79.

103 Simlonescu, 1987, p. 88.

Cristocea, Oprescu, 1988, p. 46.

195 Mârţ, 1978, p. 630.

${ }^{106}$ Cristocea, 1990 , p. 2935.

${ }^{197}$ Cristocea and co-workers, 1996, p. 26.

1 Idem, 1993/1994, p. 175.

197 1. Cantacuzino, 1981, p. 24.

10 I. Cantacuzino, 1959, p. 123.

191 Cantea, 1959, p. 99.

10 Rosetti, Panait, 1962, p. 101.

${ }^{193}$ Cantacuzino, 1959, p. 122.

194 Cantacuzino, 1959, p. 123.

105 Curinschi-Vorona, 1996, p. 209.

${ }^{166}$ Constantinescu, 1959, p. 720.

${ }^{197}$ Rosetti, 1972, p. 27.
} 
Asso, because of the hurry or negligence in construction, several cases of retreated foundations in respect with the elevation were observed, fact contradicting the principles of a accurate construction. Such cases were described at the chapel from Domnesti ${ }^{198}$ and Vieros $\mathrm{I}^{199}$, Arges district, at Polovragi, Gorj district. In the last case the foundations in retreated with about $20 \mathrm{~cm}$ in respect with the elevation ${ }^{200}$.

The interdependence between the zone of the site, the materials and the resources of the founder. Thus, river boulders were predominantly used in the hilly and mountain regions, where they were abundant.

The using of river boulders in foundation and elevation construction was established also in the case of some boyar's churches from the XVIth century, with the walls built in a careless manner showing a crude working technique, pnobably belonging to some inexperienced masons.

The archaeological researches highlighted the evolution of the brick quality, the increase in their format variety by the manufacturing of special bricks for facade and pavement decoration.

At the same time, an improvement in construction techniques and methods of byzantinian origin was noticed. Many of them are original solutions, characteristic of the Romanian architecture.

The natural specialisation process of mason masters has entailed an improvement of the working tectinique. The accumulated experience will be reflected in the construction of the XVIIth century builoings, especially of the ones belonging to the brancovinian epoch. The details on the building materials and techniques can surely offer important elements for accurate dating of different construction stages and for compilation of a calalogue of brick formats and other building materials used in the XVI-XVIIth centuries.

\section{Abbreviations}

BCMI - Comission of Historical Monuments Bulletin

BMI - Historical Monuments Bulletin, Historical and Art Monuments Series

BOR - Romanian Orthodox Church

CA - Archaeological Research, National History Museum of Romania

CAB - Archaeological Research in Bucharest, History and Art Museum of Bucharest

MCA - Archaeological Materials and Research

MO - Metropolitan Church of Oltenia

RMM - MIA - Monument and Museum Magazine - Historical and Art Monuments

SCIA - Studies and Research of Art History

SCIV - Studies and Research of Ancient History

SCIVA - Studies and Research of Ancient History and Archaeology

\footnotetext{
190 Cristocea and co-workers, 1987, p. 23.

${ }^{199}$ Cristocea and co-workers, 1996, p. 20.

200 I. Cantacuzino, 1994, p. 15.
} 

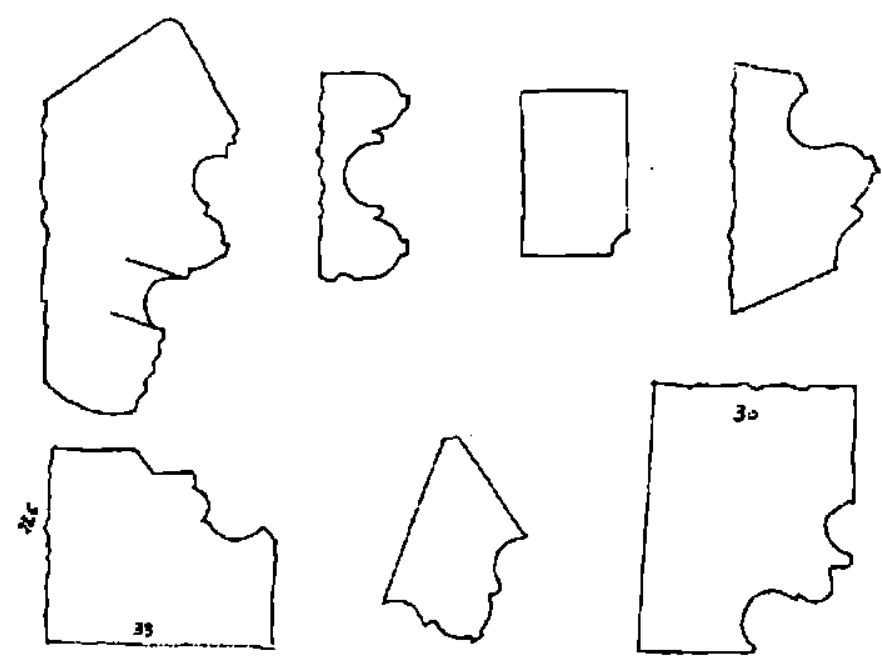

1. Stone profiles, Curtea de Argan, Royal Cour, XVI Century, P. Chihaie, p. 87

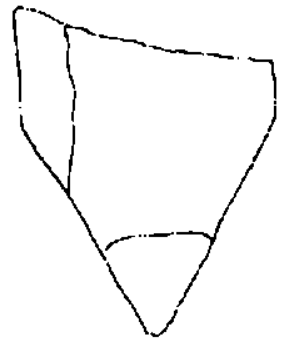

2. Enmoled tile, Royal Chuch form Throvipte, XYT Cearry, G. Minlencr, E. Prochter, 1986, 6.5. 58

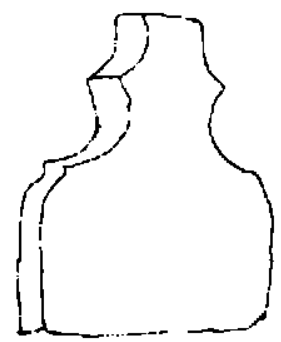

Profiled bricks from Petru Cereel' House
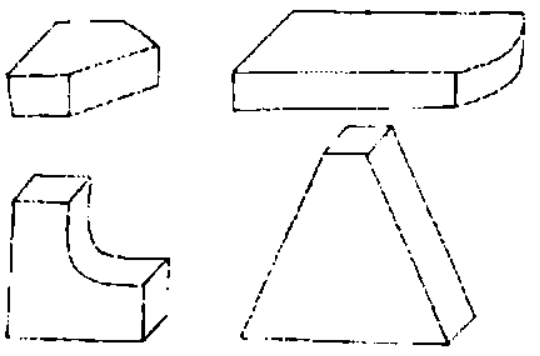

Lit-

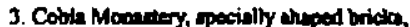
V.M. Propan DMI file 6275

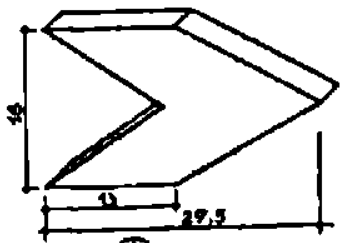

(4)

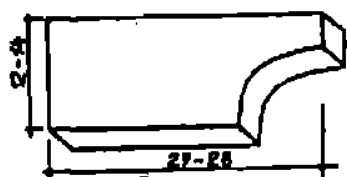

(D)

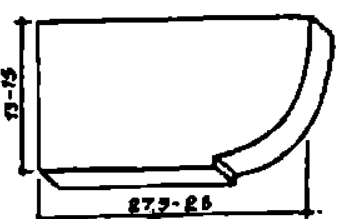

(B)

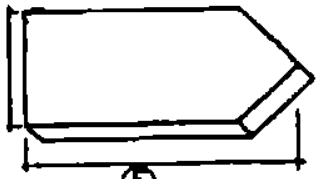

(3)

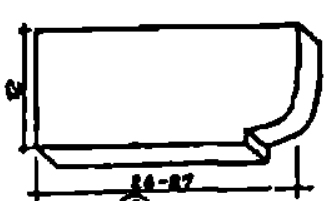

(c)

4. Types of specially shaped bricks used at the buildings from the Steles, C. Ionescu 1985, p. S0.

PL. L. Buflding materials discovered as result of the archseological researches, XVI-XVII Century 

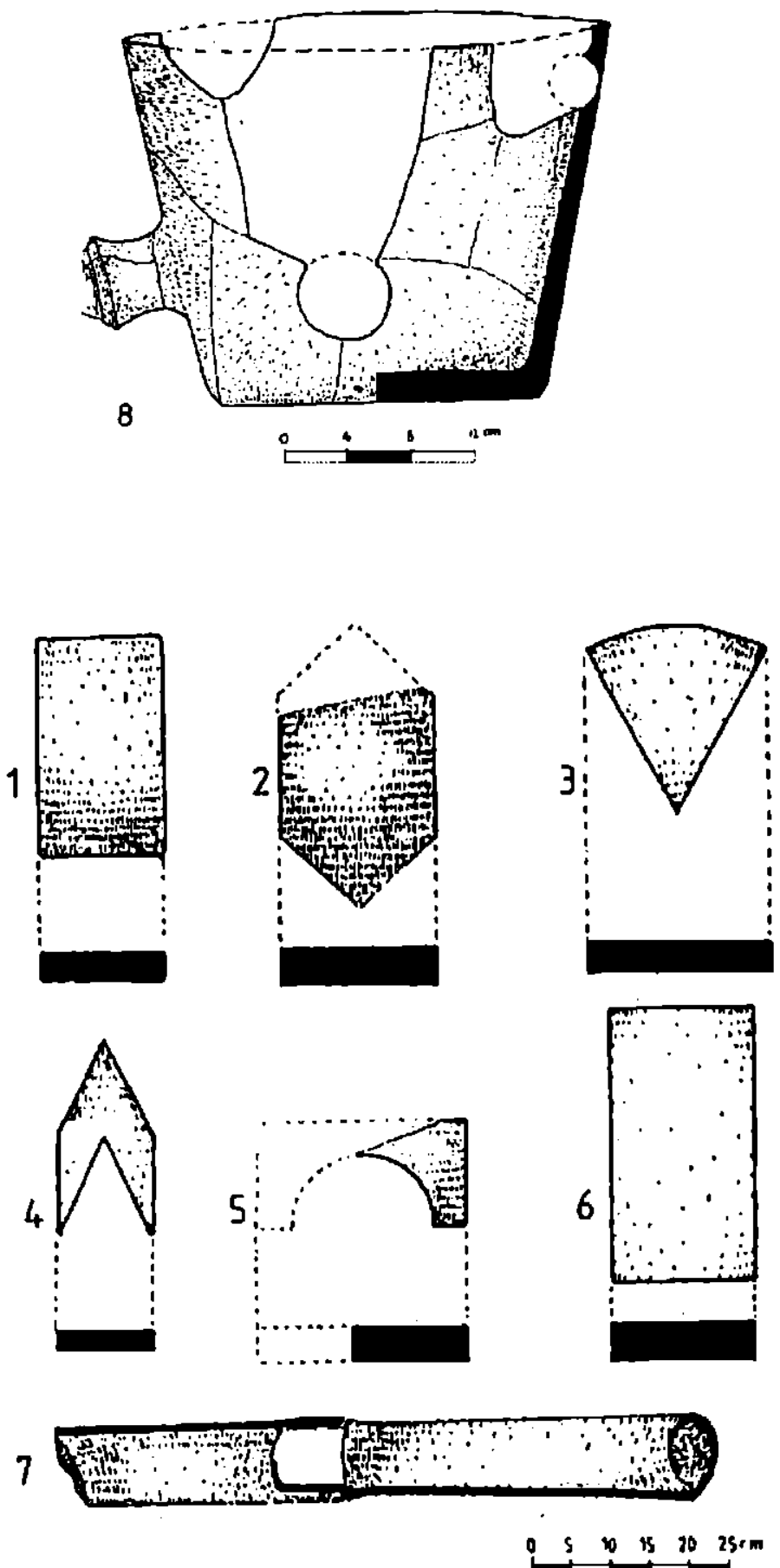

Patriarchy Targovipte. I-6 types of bricks from the XVI-XVII Century used at masonry and floors; 7 section through the first aquechuct from the early XVI Century; B. Aqueduct pottery discovered at Putriarchy of Tîngoviste, C. Diacodescu Mihăescu, RMM/1988, p. 68. 


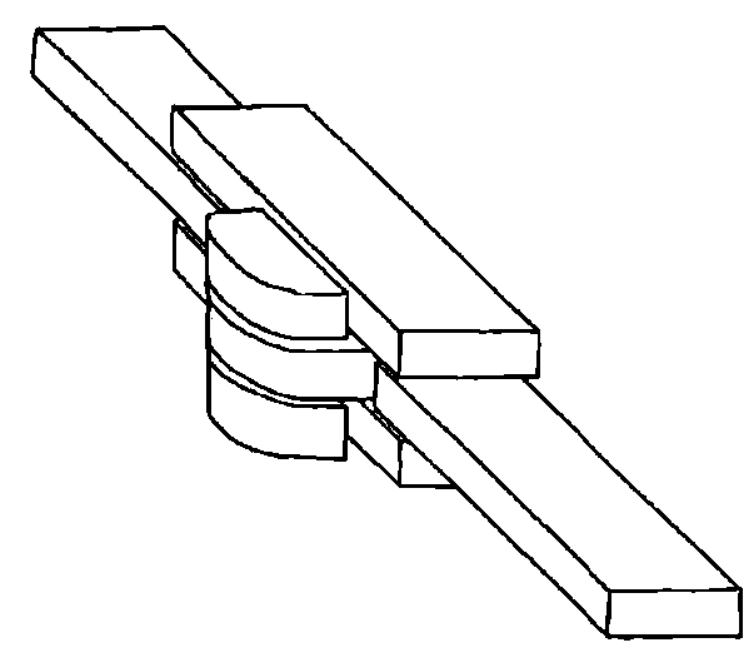

1. The building of the Mouldings that mark the limits of the churches' blind niches (bricks of the 1 and 4 type); Strehaia Monastery, V.M. Puscasu, DMI Archive, file 8618
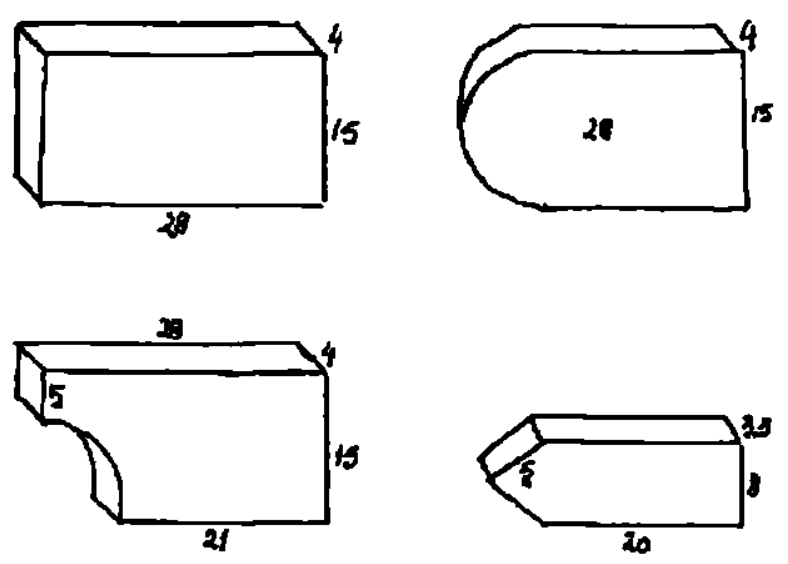

2. Original shapes of appearant bricks used for the external decoration, after BMI, 1943, XXVI, p. 70

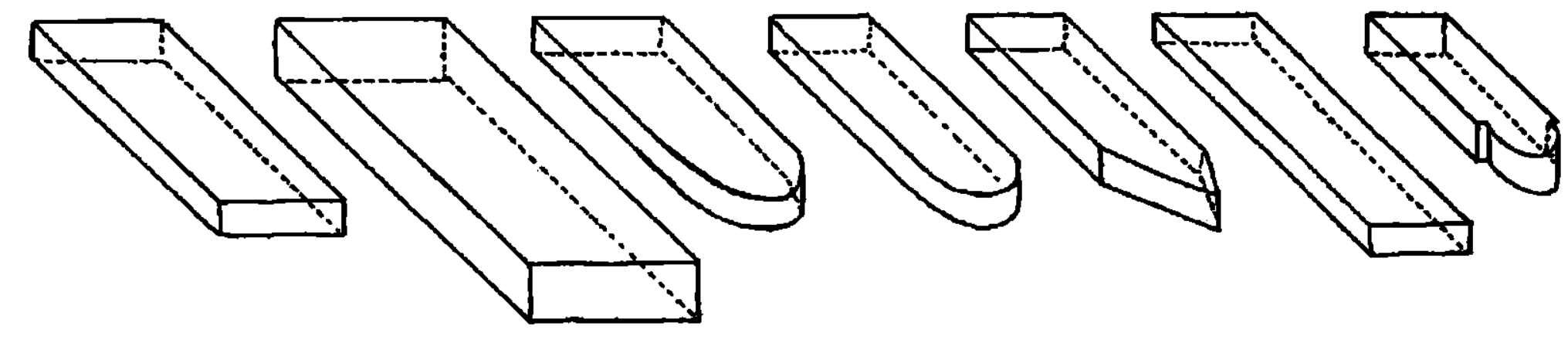

3. Brick types from the Strehaia Monastery, after V.M. Puşcaqu, pl. 6, file 8618 

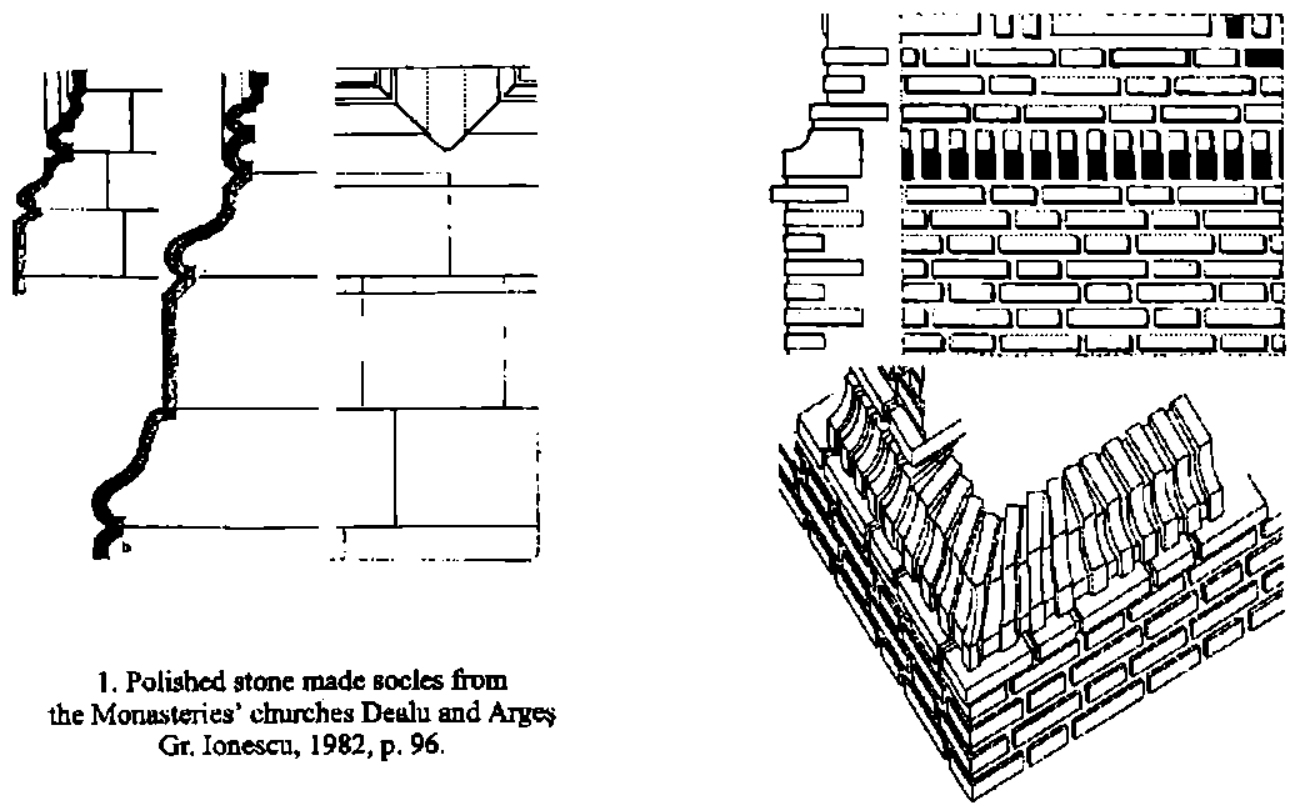

1. Polished stone made socles from the Monusteries' churches Deulu and Arges Gr. Ionescu, 1982, p. 96.

2. Brick sacle from the Curtea Veche church, Bucharest

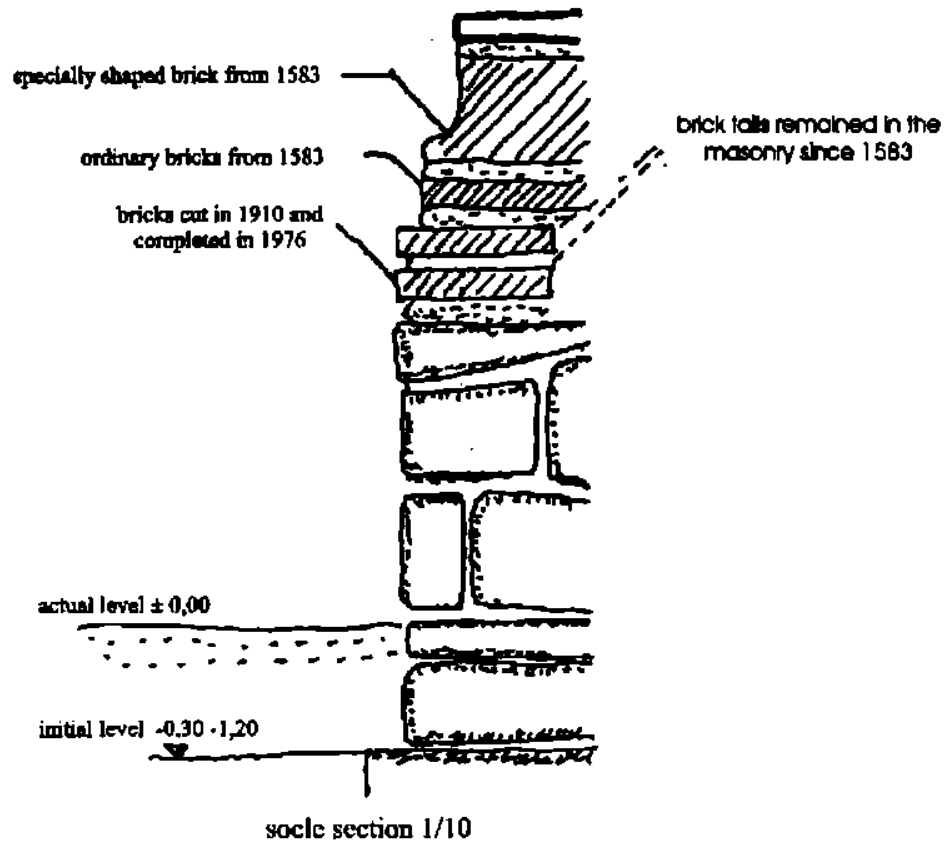

3. Socle of the Royal church from Targovişte,

after R. Mănciulescu, Scientific nueting of D.M.I., 1963, p. 36

Pl. IV. Socles types 


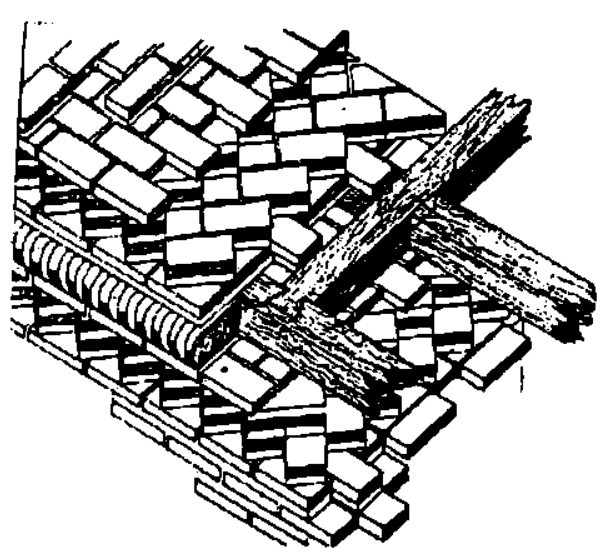

1. Wooden pullers technique H. Teodoru, 1971, Actes, p. 625.

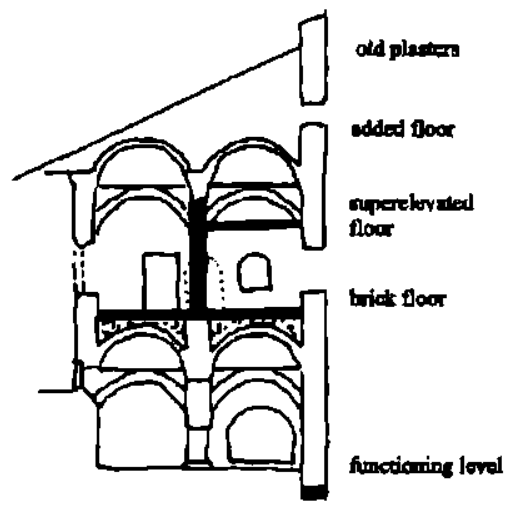

2. Wooden pilots technique, Momastery Hurez, Brancoveanu Hall (St. Balp, Studii, 1963, p. 9)

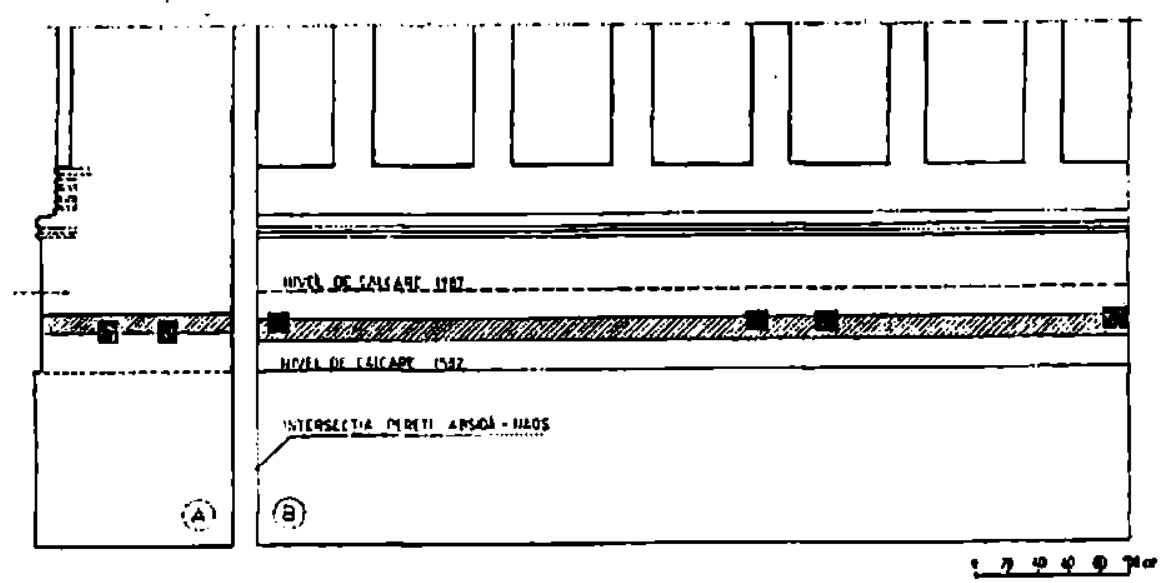

3. Pullers' distribution in the walls in the church from the Tutana Monastery (Sp. Cristocer, 1988, p. 48)

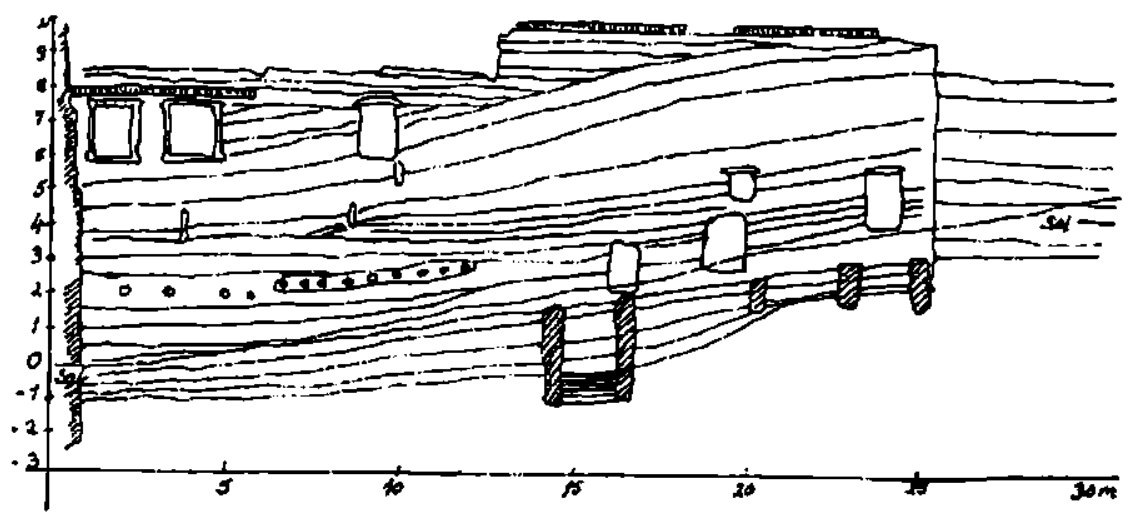

4. Wooden pilots and ataired foundation (MCA, VI, V. Vatagianu, p. 749)

The northem facade of the Brincoveni old curtain

PL. V. Building techniques, XVI - XVII Century 

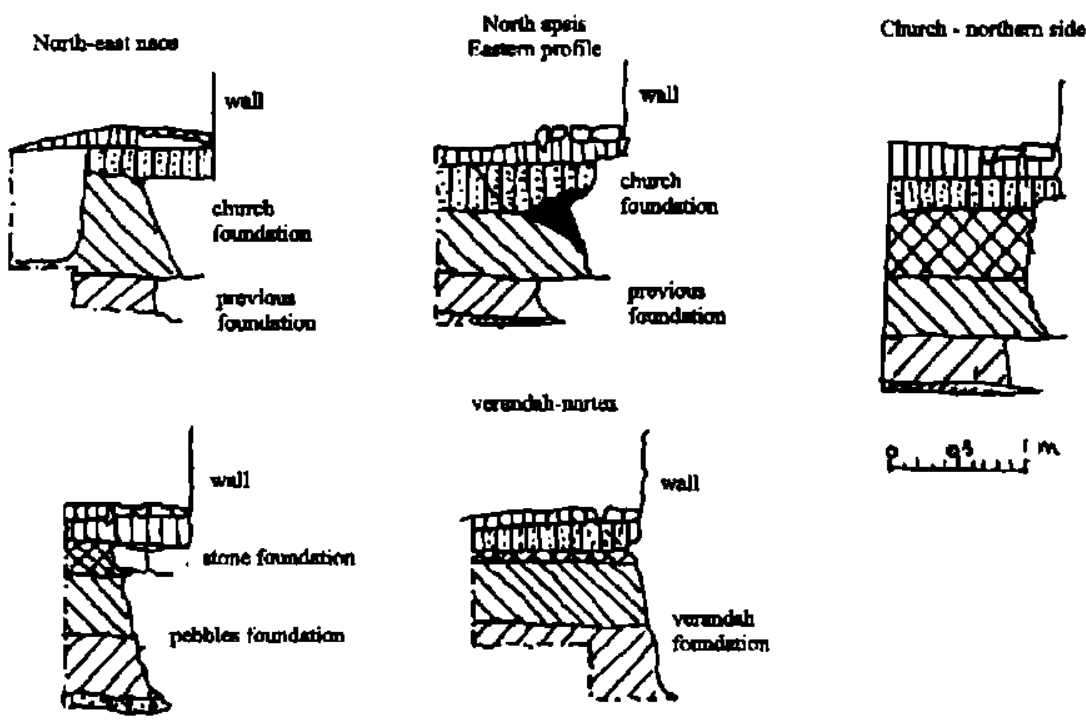

\section{R.}

1. Foumdations overlapping, Polovragi Monastery, BCMI, 1994

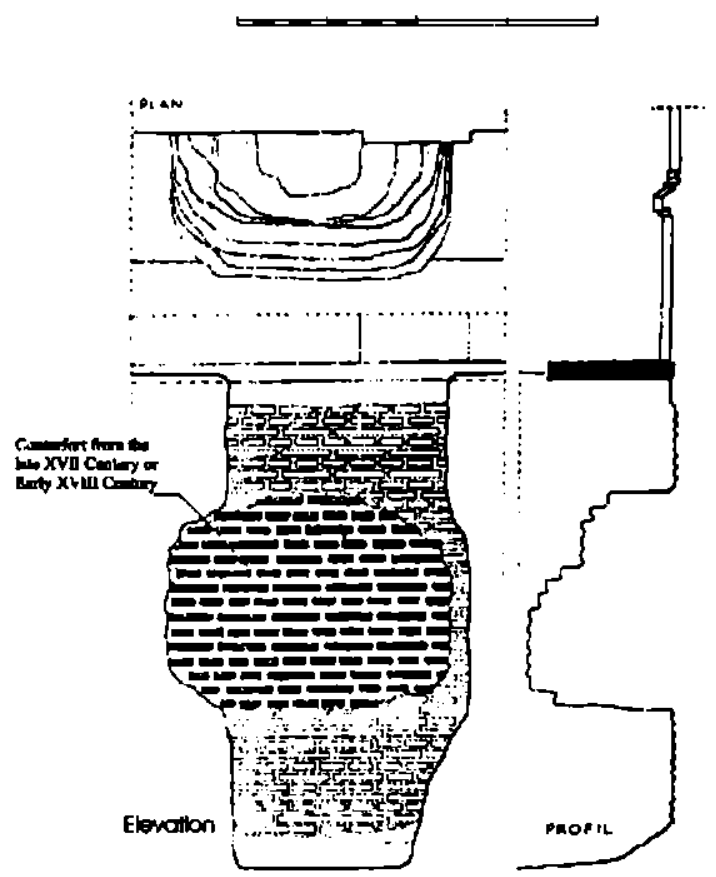

Conterfort clinged to the northers wall of the white cburch; dating fiom the end of the Late XVT Centary or Beginning of the earty XVID Century, Gh, Cantea, Bncureptii de odinicard, 1959, p. 122.

Pl. VI. Bullding techniques 


\section{BIBLIOGRAFE GENERALA}

Ghika-Budeşti - 1927-1933. Evolufia arnitecturii in Muntenia si Ottenia, B.C.M.I.

Chihaia, 1974 - Din cetăpjle de scaun ale Tării Romanești.

Bărcăcilă, 1935 - Mănăstirea Coșustea-CrivelnicuMehedinti. Descriere arheologicä, B.C.M.I.

Bătrâna, 1974 - Evolufia ansamblului fostei mănăstini Comana in lumina cercetarilor arheologice, R.M.M. $1 / 1974$

Bătrâna, 1981 - Etape de constructie în cuprinsul ansamblului Mănăstirea din Vălenii de Munte, C.A., N

Bâzu, 1971 - Restaurarea casei lui Udriște Năsturel din Heresti, B.M.I.

Cantea, (Cantacuzino), 1959 - Bucureștii de odinioară în lumina cercetărilor arheologice

Cantacuzino, 1963 - Unele probleme istorice privind assezănile muntere în lumina cercetărilor de ta Cemica, S.C.I.V.

Cantacuzino, Trohani, 1979 - Săpăturile arheologice de la Călảu Căscioarele, C.A., III

I., Cantacuzino, 1993 - Cercetările ameologice din incinta mănăstirii Mărcuła, B.C.M.I.

I. Cantacuzino, 1974 - Vechea biserica Stelea din Târgoviște, R.M.M.

I., Cantacuzino, 1980 - Sondaje arheologice la ctitoria lui Neagoe Basarab din Curtea de Argess, Studii şi Comunicări, Piteşti, V

I., Cantacuzino, 1981 - Rezultatele arheologice de la Curtea domnească de la Câmpulung, Studii și Comunicăni. Câmpulung

I., Cantacuzino, 1992 - Cercetări arheologice de la mănăstirea Govora, B.C.M.I.

1., Cantacuzino, 1994 - Cercetãn ameologice la mănãstirea Polovragi, B.C.M.I.

1. Cantacuzino, 1997 - Cronica cercetărilor arheologice, Snagov

Chicideanu, 1973 - Biserica Târgului. Raport preliminar asupra celei de-a doua campanii de sápături arheologice, Chronica Valachica

Chicideanu, Modoran, 1983 - Mănăstirea Bradu. Scurt istoric şi cerceläri arheologice, Spiritualitate și istorie la intorsura Buzăului

Chitescu si colab., 1979, 1981, 1983, 1984, 1985 Cercetănile ameologice de la Piua Petri (Orasul de Floci), C.A., III, 1979, N, 1981, V, 1982, VI, 1983, VII, 1984, VIII, 1985

Constantinescu, 1959 - Sondajele de la Ruricu-Grădinari, M.C.A., VI

Constantinescu, 1964 - Contribufii arheologice asupra curtii domneşỉ din Tárgoviște, S.C.I.V., $2 / 1964$

Constantinescu, 1965 - Cercetánile arheologice de la Cozia, M.O., $7 / 8$

Constantinescu, 1969 - Note ameologice si istorice asupra curtii feudalr de la Târgşor (sec. XIV-XVII), S.C.I.V.A.

Constantinescu, 1984 - Curtea de Argeș. Inceputurile Tării Româneşti, 1200-1400

Constantinescu, Moisescu, 1969 - Curtea domnească din Târgoviște

Cristocea şi colab., 1987 - Cercetănile arheologice de la Domneşti, jud. Arges, Studii și Comunicări, Câmpulung

Cristocea, Oprescu, 1988 - Cercetările anheologice de la mănăstiraa Tutana și probleraa încadrării unui triconc de la cumpăna sec. XIV-XV, R.M.M.

Cristocea, 1990 - Biserica Drujești din Curtea de Arges, R.M.M., $1 / 1990$

Cristocea și colab., 1993/1994 - Cercetärile ameologice de la mănăstirea Råncăciov, jud. Arges, R.M.M. 1993/1994
Cristocea şi colab., 1996 - Cercetănile arheologice de la fosta mânăstire Vieros, judeful Arges, R.M.M.

Curinschi-Vorona, 1996 - Artitectură, restaurare, urbanism, 1996

Diaconescu, 1971 - Cercetarea arheologică de la biserica Sf. Ionică din Târgovişte, Documenta Valachica

Diaconescu, Mihăescu, 1988 - Complexul monumental al mitropoliei din Tărgovişte, R.M.M.

Drăghiceanu, 1964 - Despre mănăstirea Câmpulung, Un document inedit: jumalul săpăturilor făcute de Comisia Monumentelor Istorice in 1924, B.O.R.

Drăguț, 1976 - Dicfionar enciclopedic de antă medievală românească

Dråmbocianu, 1993 - Stapiunea de la Vadu-Sorești, jud. Buzău, M.C.A., XVII, vol. II, 1993

Dumitriu, 1992 - Evolufia fostei mănăstiri Cobia în lumina cercetärilor arheologice, B.C.M.I., 2/1992 lonescu, 1982 - Istoria amitecturii in România

Lupu, 1994 - Date arheologice privind mănăstirea ,Adormirea Maicil Domnului" din Râmnicu-Sărat, judeł̧ul Buzău (secolele XVI-XIX), Mousaios, 1994

Mănciulescu, 1963 - Date noi referitoare la aspectul inifial al bisericii domneşti din Târgoviște, apărute in cursul lucrărilor de restaurare (1961-1962), Sesiunea Știintificã a DMI

Mârłu, 1978 - Mănăstirea Valea (Titeşti-Arges) în lumina controverselor istoriografice și a cercetärilor arheologice, M.O. 7-8/1978

Mihăescu, Fruchter, 1986 - Curtea domnească din Tárgoviste, 1986

Moisescu, 1979 - Târgoviște. Monumente istorice și de artā

Moisescu, 1985 - Procedee tehnice, materiale si mesteri constructori români in Evul mediu, R.M.M.

Noica, 1997 - Traditii româneşti în construcfiile de lucrări publice

Popescu-Cilieni, 1945 - Acoperişurile vechilor noastre biserici

Rădulescu, 1984 - Cercetarnile arheologice de la Ursafi, jud. Gorj, C.A., VII

Rosetti, 1962 - Cercetårile de la mănăstirea Hurezu, M.C.A., VIII

Rosetii, 1972 - Vestigiile feudale de la Suslănești, jud. Arges, B.C.M.I.

Rosetti, Panait, 1962 - Cercetärile de la biserica Sf. Gheorghe Nou din Bucuresti, MCA, VIII,

Panait, 1962 - Complexul medieval Tânganu, C.A.B., II,

Panait, 1992 - Cercetări arheologice privind biserica mănăstirii Cotroceni, R.M.M.

Puşcaşu, 1970 - Date noi cu privire la evolufia ansamblului de artitectură medievală de la Strehaia, B.M.I.

Simionescu, 1987 - Contributii la studiul monumentului Beştelei din Pitesti

Ștefănescu, 1993-1994 - Cercetări privind istoria ansamblului Sf. Spinidon Vechi din Bucuresti, R.M.M., 1-2 1993/1994

Teodoru, 1975 - La tradition byzantine des chainages dans l'architecture de Valachie, Actes du XIV Congres international des Etudes Byzantines

Theodorescu, 1968 - Un monument uitat din Muntenia medievală: Cătăluiul, S.C.I.A.

Vătăşianu şi colab., 1959 - Cercetănile arheologice de la mảnãstirea Brâncoveni, M.C.A., VI 